\title{
Retail Investors' Responsibilities in Stock Market Imperfection in Bangladesh: An Empirical Study
}

\author{
Protap Kumar Ghosh \\ Assistant Professor, Business Administration Discipline \\ Khulna University, Khulna-9208, Bangladesh \\ E-mail: pkghosh1982@gmail.com \\ Sutap Kumar Ghosh \\ Assistant Professor, Finance and Banking Department \\ Islamic University, Khustia, Bangladesh \\ E-mail: ansutap@gmail.com
}

Received: August 19, 2015 Accepted: Sep. 29, 2015 Published: December 1, 2015

doi:10.5296/ajfa.v7i2.8175 URL: http://dx.doi.org/10.5296/ajfa.v7i2.8175

\begin{abstract}
Because of frequent price instability, stock market in Bangladesh represents itself an imperfect one over times. The retail investors claim that these frequent price fluctuation in the market is due to price manipulation, presence of syndicate and improper control by regulatory bodies and so on. But this study has found that a great portion of retail investors are very micro investors and reluctant in using relevant information in stock trading and furthermore ridiculously influenced by others investors and brokerage house personnel. Most of them consider only trend of past prices and market index. Majority of our respondents never considered net asset per share although it might give an idea about market value per share. So, the whole responsibilities of this price volatility and market imperfection can't be shifted to third parties solely; retail investor themselves are responsible to some extent due to their irrational behavior and high expectation from stock trading. Stock market perfection in Bangladesh is quite impossible without enhancing awareness among retail investors and ensuring their rational behavior in stock trading.
\end{abstract}

Keywords: Stock market, Market imperfection, Retail investors, Factor analysis, Investors responsibilities 


\section{Introduction}

There are two stock exchanges in Bangladesh; one is Dhaka stock Exchange and another one is Chittagong Stock Exchange. Since their establishment, during the last two decades these two markets experienced two big crashes in 1996 and 2011. About 35million people lost their entire investment in 2011. Even after these two big crashes, Bangladesh stock market cannot represent itself stable over times. The market index has been fluctuating frequently without any foreseeable change in relevant factors. The retail investors have been claiming that this unstable situation is a product of price manipulation, insider trading; lack of adequate control, lack of suitable policies and intervention by regulatory bodies, presence of syndicate so on. Several research studies were conducted by (Chowdhury \& Abdullah, 2011; Haque \& Faruquee. , 2013 ; Ghosh, P. K., Bose, T. K. \& Shahriar, M, 2012) and supported the claim of the retail investors. But retail investors cannot blame that this instability in the stock market is just only for the lack of proper polices and intervention by the regulatory bodies in Bangladesh. Retail investors should not rebuff their responsibilities in market imperfection because whenever making investment decision, by considering relevant factors and using proper valuation technique to some extent they can reduce their investment risk as well as price manipulation of the stock market and can play an active role in the process of building perfect capital market. The objectives of this study are:

1. To represent the important variables that are considered by the retail investors in stock trading.

2. To develop the core factors that influence the retail investors in making investment decision and to show its relative importance.

3. To represent the overall usages of these variables to denote their responsibilities in market imperfection and lastly to draw their attention in order to making them rational in stock trading.

\section{Literature review}

Wide fluctuation in stock prices has become a common phenomenon in Dhaka Stock Exchange (DSE); even it was also seen during last few couple of years. Weak market regulation, limited number of good IPOs, lack of accounting knowledge of the investor and presence of syndicate (Chowdhury \& Abdullah , 2011), corruption in regulatory organization, margin loan, direct listing, insider trading, bookbuilding method, unskilled investors and intervention of Bangladesh bank, faulty listing method, IPO overpricing, small number of new listing, revaluation of asset before company's listing, high premium on issuance of right share, stock split, stock price manipulation, Investors' high expectation and irrational behavior (Haque, \& Faruquee , 2013) cause undue increase in market index and ultimately result in great fall in Stock market. Ghosh, Bose and Shahriar (2012) also concluded that price manipulation, insider trading, faulty financial statement, improper dividend policy and lack of appropriate policy by central bank hampered smooth operation in Bangladesh capital market. Stock markets are expected to accelerate economic growth by providing a boost to domestic savings and increasing the quantity and the quality of 
investment (Yartey, 2008). Bangladesh Bank (central bank of Bangladesh) and Securities and Exchange Commission took some initiatives during last few years to stabilize the stock market in Bangladesh but still now the market is unstable.

Different scholars in different countries tried to identify the determinants of stock prices. Most of them tried to recognize a link among accounting information as well as macroeconomic elements of the country and stock price movement. In a study by Kumar \& Hundal (1986) on Asian share market found a positive link of earning per share, dividend per share, net asset per share and leverage ratios on stock price. A positive link between earning per share and market value of stock was also found by Malhotra (1987); Baskin, (1989) ; Tuli, Nishi \& Mittal, R.K. (2001). In Australia, book value was more significant than earnings of the organization in equity valuation (Ohlson, 1995). In a study by Bayezid \& Tanbir (2010) found that announcement of dividend has a significant impact on stock price movement.

Piotroski. \& Roulstone (2004) concluded that market prices of the stock depends on demand-supply forces of a particular security in the stock market. Several researchers also concluded that accounting reporting influenced the market value of corporate stock (Svensson \& Larsson, 2009; AL-Shubiri, 2010; Sharma, 2011; Andriantomo \& Yudianti , 2013 ; Bhatt \& Sumangula, 2012 ; Halonen, Pavlovic and Persson , 2013). Besides accounting information, some macro and micro economic factors also affect market value of shares (AL-Shubiri , 2010). Gross domestic products, interest rates, current account, and employment have an impact on stock prices movement (Kurihara, 2006). Exchange rate, money supply, consumer prices and industrial production have strong relationship with stock prices (Ibrahim, 1999; Dimitrios, 2003).

All the above review of past literature tried to link between secondary data and stock price movement. The context and demographic features of the retail investors in Bangladesh are different from that of developed and other developing countries. So, this study has been designed based on primary data incorporating the responses of the retail investors to identify the factors that are considered by them and the level of usages of those factors so that their responsibilities in capital market imperfection can be detected and eventually they can be aware in stock trading.

\section{Methodology}

This section is divided into four parts; variables selection, questionnaire development, sampling \& data collection and data analysis.

\subsection{Variables Selection}

The initial base of our variable selection was intensive review of past relevant literatures. Firstly, we tried to find out the determinants of stock prices though review of past literatures and then went for interviewing retail investors at four different brokerage houses in Khulna to have a tentative idea about the variables they consider while making investment decision. From this pilot survey and review of past literatures, we finally developed 5 demographic variables to provide an idea about the demographic nature of the respondents and 26 ordinal 
variables to conduct our statistical analysis to reach our research findings.

\subsection{Questionnaire Development}

This study was mainly a descriptive one and questions were close-ended in nature. In the first part of the questionnaire, 5 variables were designed in order to obtaining demographic information of the respondents so that it can represent tentative demographic features of Bangladeshi retail investors. In the second part of the questionnaire, 26 variables were designed to collect the opinion of the retail investors on how they used these selected variables in their decision making. A 4 point scale was used for the last 26 variables, where 1 denoted "Never Used", 2 denoted "Rarely Used", 3 denoted "Frequently Used" and finally 4 denoted "Always Used".

\subsection{Sampling \& Data Collection}

This study was mainly based on primary data. The population of this study was all the retail investors in Khulna and Dhaka cities. To collect our required data, 180 respondents were selected randomly from different brokerage houses in Khulna and Dhaka. The questionnaires were supplied to the respondents accordingly and the reason behind using random sampling was to ensure our research findings bias free. After collecting and checking the completeness of these filled in questionnaires, 150 responses were finally selected for analysis.

\subsection{Data Analysis}

Before using the statistical tools, we tested the reliability of our questionnaire and the value of Cronbach's Alpha $(\alpha)$ was 0.894 that represented high reliability of the questionnaire. To find the core factors that influenced the retail investors' buying decisions, factor analysis was done and the value of Kaiser-Meyer-Olkin test was 0.825 which indicated sampling adequacy (adequacy of variables) to run factor analysis. Bartlett's Test of Sphericity represents that the value of Chi-square $\left(\chi^{2}\right)$ is 2.083 as well as the associated P-value is 0.000 that indicate multivariate normality of set of distributions that means the data set will not produce an identity matrix. The variables having more than 0.500 loading in rotated component matrix were included into a particular factor. After conducting factor analysis, descriptive statistical analysis by frequency distribution were done to represent level of usages of each variable while making investment decision by the retail investors in order to showing their contribution in capital market imperfection.

\section{Analysis and Findings:}

This section was divided into four parts. First part involved demographic analysis of the respondent. 2nd part involved relative importance of the selected variables using mean score; third part held factor analysis to identify key factors that influence investors' buying decision and its relative importance in decision making. The final part of this section included descriptive analysis of the variable in order to showing the level of usages of the variables aggregated under different factors. 


\subsection{Demographic Profile of the Respondents}

Demographic findings of our respondents represented that most of our retail investors were male and their age limit were between 25 to 40 years. We found that education level of $32 \%$ of our respondents was HSC \& below and it represented that having this education level, those retail investors might not have the sophisticated stock valuation skill. Mainly service holders and businessmen were the dominant investors in Bangladeshi stock market. If we analyze the amount of investment of the respondents, we saw that most of the respondents were micro investors having investment below BDT 500,000 (where \$1 $=$ BDT 80 approximately). As respondents were selected randomly, it might represent an approximate scenario of our retail investors.

Table 1. Demographic features of the respondent

\begin{tabular}{|c|c|c|c|}
\hline $\begin{array}{l}\text { Demographic } \\
\text { Features }\end{array}$ & Classes & Frequency & Percentage \\
\hline \multirow[b]{2}{*}{ Gender } & Male & 133 & 88.7 \\
\hline & Female & 17 & 11.3 \\
\hline \multirow{3}{*}{ Age } & Lowest to 25 & 18 & 12.0 \\
\hline & 25 to 40 & 99 & 66.0 \\
\hline & $40 \&$ above & 33 & 22.0 \\
\hline \multirow{3}{*}{$\begin{array}{c}\text { Educational } \\
\text { Level }\end{array}$} & HSC \& below & 48 & 32.0 \\
\hline & Graduate & 44 & 29.3 \\
\hline & Post Graduate & 58 & 38.7 \\
\hline \multirow{3}{*}{ Profession } & Service Holder & 54 & 36.0 \\
\hline & Business & 74 & 49.3 \\
\hline & Others & 22 & 14.7 \\
\hline \multirow{4}{*}{ Investment (in BDT) } & Below 500,000 & 96 & 64.0 \\
\hline & 500,000 to $1,000,000$ & 33 & 22.0 \\
\hline & $1,000,000$ to $1,500,000$ & 7 & 4.7 \\
\hline & Above $1,500,000$ & 14 & 9.3 \\
\hline
\end{tabular}

\subsection{Relative Importance of the Selected Variables}

The table two holds relative importance of the variables to the respondents in decision making process. We saw that out of 26 variables only 5 variables crossed the frequently used level having mean score more than 3.00. The variables "Fluctuation in market index", "Past prices of the stock", "Reputation of the company", "Dividend declaration" and "Earning per share" were seen most frequently used variables in stock trading. Then the next 8 variables cross rarely used level in our four point scale. Out of them, the mean score of the variable "Political stability" was very much close to the frequently used level that indicated it relative importance in stock trading. Other two variables "Release of new products or services" and "Dividend payout ratio" were seen important to the respondent as mode value of these two variables was 4 . The rest of the variables remained below rarely used level in four point scale .It was also seen that from one to eight ranked variables had mode value 4 that meant 
major group of the respondents always used these variables. The rest of the variables, except "Recommendation from other investors" whose mode value was two, had mode value one that meant greater part of the respondents didn't use those variables.

Table 2. Ranking of the variables based on mean score

\begin{tabular}{|c|c|c|c|c|}
\hline Rank & Name of the variables & Mean & $\begin{array}{c}\text { Std. } \\
\text { Deviation }\end{array}$ & Mode \\
\hline 1 & Fluctuations in market index & 3.56 & .790 & 4 \\
\hline 2 & Past Price of the stock & 3.56 & .790 & 4 \\
\hline 3 & Reputation of the company & 3.49 & .766 & 4 \\
\hline 4 & Dividend declaration & 3.41 & .796 & 4 \\
\hline 5 & Earnings per share & 3.31 & 1.068 & 4 \\
\hline 6 & Political stability & 2.83 & 1.096 & 4 \\
\hline 7 & $\begin{array}{l}\text { Release of new products or } \\
\text { services }\end{array}$ & 2.67 & 1.150 & 4 \\
\hline 8 & Dividend payout ratio & 2.62 & 1.197 & 4 \\
\hline 9 & Changes in govt. Policies & 2.49 & 1.273 & 1 \\
\hline 10 & Net asset per share & 2.37 & 1.383 & 1 \\
\hline 11 & Debt-equity ratio & 2.10 & 1.151 & 1 \\
\hline 12 & Return on asset ratio & 2.03 & 1.184 & 1 \\
\hline 13 & $\begin{array}{l}\text { Recommendation from other } \\
\text { investors }\end{array}$ & 2.01 & .867 & 2 \\
\hline 14 & Return on equity ratio & 1.97 & 1.144 & 1 \\
\hline 15 & SEC intervention & 1.91 & 1.061 & 1 \\
\hline 16 & \begin{tabular}{|lc} 
Recommendations & from \\
brokerage house
\end{tabular} & 1.91 & .907 & 1 \\
\hline 17 & GDP & 1.81 & 1.109 & 1 \\
\hline 18 & Insider information & 1.73 & .974 & 1 \\
\hline 19 & Global financial aspect & 1.66 & .858 & 1 \\
\hline 20 & Margin loan facilities & 1.66 & .954 & 1 \\
\hline 21 & Free cash flow & 1.65 & 1.017 & 1 \\
\hline 22 & Expert opinion & 1.63 & .886 & 1 \\
\hline 23 & Rate of interest & 1.62 & .981 & 1 \\
\hline 24 & Cash reinvestment ratio & 1.53 & 1.008 & 1 \\
\hline 25 & Rate of inflation & 1.50 & .880 & 1 \\
\hline 26 & $\begin{array}{l}\text { Currency } \quad \text { exchange } \\
\text { fluctuation }\end{array}$ & 1.48 & .888 & 1 \\
\hline
\end{tabular}




\subsection{Factors Affecting Investors’ Trading Decision}

Factor analysis was done to construct the core factors that influenced the retail investors in stock trading and eventually seven factors had been extracted. Only the variable "SEC intervention" had been excluded from seven factors generated in table three. From appendix-2, the name of factors and the loading of respective variables under those factors are summarized in table three.

Table 3. Loading of the variables under seven components through factor analysis

\begin{tabular}{|c|c|c|c|}
\hline $\begin{array}{c}\text { Factor } \\
\mathrm{S}\end{array}$ & Name of the variables & Loading & Name of the factors \\
\hline \multirow{7}{*}{1} & Return on asset ratio & .838 & \multirow{7}{*}{$\begin{array}{l}\text { Overall financial } \\
\text { position }\end{array}$} \\
\hline & Return on equity ratio & .834 & \\
\hline & Free cash flow & .759 & \\
\hline & Cash reinvestment ratio & .758 & \\
\hline & Debt-equity ratio & .725 & \\
\hline & Net asset per share & .679 & \\
\hline & Dividend payout ratio & .601 & \\
\hline \multirow{5}{*}{2} & Rate of inflation & .852 & \multirow{5}{*}{$\begin{array}{l}\text { Macroeconomic } \\
\text { Elements }\end{array}$} \\
\hline & Currency exchange rate fluctuation & .739 & \\
\hline & GDP & .696 & \\
\hline & Global financial aspect & .673 & \\
\hline & Changes in govt. Policies & .588 & \\
\hline \multirow{5}{*}{3} & Past Price of the stock & .844 & \multirow{5}{*}{$\begin{array}{c}\text { Stock performance } \& \\
\text { Company reputation }\end{array}$} \\
\hline & Reputation of the company & .757 & \\
\hline & Dividend declaration & .720 & \\
\hline & Fluctuations in market index & .649 & \\
\hline & Release of new products or services & .582 & \\
\hline \multirow{3}{*}{4} & Expert opinion & .716 & \multirow{3}{*}{$\begin{array}{l}\text { Political environment } \\
\& \text { Private information }\end{array}$} \\
\hline & Political stability & .681 & \\
\hline & Insider information & .545 & \\
\hline \multirow[t]{2}{*}{5} & $\begin{array}{l}\text { Recommendations from brokerage } \\
\text { house }\end{array}$ & .888 & \multirow{2}{*}{$\begin{array}{l}\text { Others' } \\
\text { recommendation }\end{array}$} \\
\hline & Recommendation from other investors & .821 & \\
\hline \multirow[t]{2}{*}{6} & Rate of interest & .806 & \multirow[b]{2}{*}{ Margin Loan facilities } \\
\hline & Margin loan facilities & .789 & \\
\hline 7 & Earnings per share & .710 & Earnings per share \\
\hline
\end{tabular}

Although "Earning per share" is a part of overall financial performance, it was separated as individual factor than other financial performance indicators of the company. If we see the grand mean of each factor in table-4, we find that the factors "Stock performance \& company 
reputation" in the market was given most priority in stock trading having highest grand mean score 3.34 and the "Earning per share" was given second priority having mean value 3.31. In the same way other factors "Political environment \& Private information", "Overall financial position", "Others' recommendation", "Macroeconomic Elements" and lastly "Margin Loan facilities" got third, fourth, fifth, sixth and seventh rank respectively based on its grand mean score but all the grand means were very much close to rarely used or below rarely used level. It should be noted here that although seven factors are identified here, not all factors are used by the respondents evenly.

\subsection{Level of Usages of the Variables by the Investors}

Table four holds the grand means of all the factors along with detail frequency distribution of usages of the variables aggregated under each factor. Only two factors "Stock performance \& Company reputation" and "Earnings per share" passed frequently used level in four point scales. But no one variable under these two factors was seen always usages by $100 \%$ respondents while making investment decision. Price of a particular stock should be based on financial position of the relevant company and so many researchers tried to link between financial performance indicators and stock price movement. But more unexpectedly the grand mean of the factor "Overall financial position" was only 2.04 that was very close to rarely used level and the variable "Net asset per share" was seen always usages by only $37.3 \%$ respondents. The review of past literature has proved that macroeconomic factors and stock price movement are closely linked but the variables aggregated under this factor disclosed that investors were not very much concern for macroeconomic elements in stock trading. A great number of investors never considered the variables under this factor in investment decision. It was identified that the rest of the variables, aggregated under the remaining factors, were not widely used by the retail investors in stock trading as well.

Table 4. Descriptive statistics of the factors constructed

\begin{tabular}{|c|c|c|c|c|c|c|c|}
\hline Factor & Name of the variables & $\begin{array}{c}\text { Never } \\
\text { used }\end{array}$ & $\begin{array}{l}\text { Rarely } \\
\text { used }\end{array}$ & $\begin{array}{l}\text { Frequently } \\
\text { used }\end{array}$ & $\begin{array}{c}\text { Always } \\
\text { used }\end{array}$ & Mean & S.D. \\
\hline \multirow{8}{*}{1} & $\begin{array}{l}\text { Dividend payout } \\
\text { ratio }\end{array}$ & $27.3 \%$ & $15.3 \%$ & $25.3 \%$ & $32.1 \%$ & 2.62 & 1.197 \\
\hline & Net asset per share & $46 \%$ & $8.7 \%$ & $8 \%$ & $37.3 \%$ & 2.37 & 1.383 \\
\hline & Debt-equity ratio & $49.1 \%$ & $19.3 \%$ & $19.3 \%$ & $17.3 \%$ & 2.10 & 1.151 \\
\hline & Return on asset ratio & $49.3 \%$ & $16.7 \%$ & $15.3 \%$ & $18.7 \%$ & 2.03 & 1.184 \\
\hline & $\begin{array}{l}\text { Return on equity } \\
\text { ratio }\end{array}$ & $50 \%$ & $20 \%$ & $13.3 \%$ & $16.7 \%$ & 1.97 & 1.144 \\
\hline & Free cash flow & $64 \%$ & $17.3 \%$ & $8 \%$ & $10.7 \%$ & 1.65 & 1.017 \\
\hline & $\begin{array}{l}\text { Cash reinvestment } \\
\text { ratio }\end{array}$ & $74.7 \%$ & $7.3 \%$ & $8 \%$ & $10 \%$ & 1.53 & 1.008 \\
\hline & \multicolumn{5}{|c|}{ Grand mean of the factor "Overall financial position" } & 2.04 & 0.932 \\
\hline & $\begin{array}{l}\text { Changes in govt. } \\
\text { Policies }\end{array}$ & $36.7 \%$ & $9.3 \%$ & $22.7 \%$ & $31.3 \%$ & 2.49 & 1.273 \\
\hline
\end{tabular}




\begin{tabular}{|c|c|c|c|c|c|c|c|}
\hline \multirow{5}{*}{2} & GDP & $60 \%$ & $12 \%$ & $15.3 \%$ & $12.7 \%$ & 1.81 & 1.109 \\
\hline & $\begin{array}{l}\text { Global financial } \\
\text { aspect }\end{array}$ & $55.3 \%$ & $27.3 \%$ & $13.3 \%$ & $4.1 \%$ & 1.66 & 0.858 \\
\hline & Rate of inflation & $70 \%$ & $16 \%$ & $8 \%$ & $6 \%$ & 1.50 & 0.880 \\
\hline & $\begin{array}{l}\text { Currency exchange } \\
\text { rate fluctuation }\end{array}$ & $72 \%$ & $14.6 \%$ & $6.7 \%$ & $6.7 \%$ & 1.48 & 0.888 \\
\hline & \multicolumn{5}{|c|}{ Grand mean of the factor "Macroeconomic Elements" } & 1.79 & .782 \\
\hline \multirow{6}{*}{3} & $\begin{array}{l}\text { Past Price of the } \\
\text { stock }\end{array}$ & $4 \%$ & $6.6 \%$ & $18.7 \%$ & $70.7 \%$ & 3.56 & 0.790 \\
\hline & $\begin{array}{l}\text { Fluctuations in } \\
\text { market index }\end{array}$ & $4.7 \%$ & $4.6 \%$ & $20.7 \%$ & $70 \%$ & 3.56 & 0.790 \\
\hline & $\begin{array}{l}\text { Reputation of the } \\
\text { company }\end{array}$ & $3.3 \%$ & $6.7 \%$ & $27.3 \%$ & $62.7 \%$ & 3.49 & 0.766 \\
\hline & Dividend declaration & $3.3 \%$ & $9.4 \%$ & $30 \%$ & $57.3 \%$ & 3.41 & 0.796 \\
\hline & $\begin{array}{l}\text { Release of new } \\
\text { products or services }\end{array}$ & $20 \%$ & $27.3 \%$ & $18 \%$ & $34.7 \%$ & 2.67 & 1.150 \\
\hline & \multicolumn{5}{|c|}{$\begin{array}{l}\text { Grand mean of the factor "Stock performance \& Company } \\
\text { reputation" }\end{array}$} & 3.34 & 0.645 \\
\hline \multirow{4}{*}{4} & Political stability & $15.3 \%$ & $23.1 \%$ & $24.3 \%$ & $37.3 \%$ & 2.83 & 1.096 \\
\hline & Insider information & $55.3 \%$ & $24.7 \%$ & $11.3 \%$ & $8.7 \%$ & 1.73 & 0.974 \\
\hline & Expert opinion & $59.3 \%$ & $24 \%$ & $11.3 \%$ & $5.3 \%$ & 1.63 & 0.886 \\
\hline & \multicolumn{5}{|c|}{$\begin{array}{l}\text { Grand mean of the factor "Political environment \& Private } \\
\text { information" }\end{array}$} & 2.06 & 0.727 \\
\hline \multirow{3}{*}{5} & $\begin{array}{l}\text { Recommendation } \\
\text { from other investors }\end{array}$ & $33.3 \%$ & $35.3 \%$ & $28 \%$ & $3.4 \%$ & 2.01 & 0.867 \\
\hline & $\begin{array}{l}\text { Recommendations } \\
\text { from brokerage house }\end{array}$ & $39.3 \%$ & $37.3 \%$ & $16.7 \%$ & $6.7 \%$ & 1.91 & 0.907 \\
\hline & \multicolumn{5}{|c|}{ Grand mean of the factor "Others' recommendation" } & 1.96 & 0.789 \\
\hline \multirow{3}{*}{6} & Margin loan facilities & $60 \%$ & $22 \%$ & $10 \%$ & $8 \%$ & 1.66 & 0.954 \\
\hline & Rate of interest & $64.7 \%$ & $18 \%$ & $8 \%$ & $9.3 \%$ & 1.62 & 0.981 \\
\hline & \multicolumn{5}{|c|}{ Grand mean of the factor "Margin Loan facilities" } & 1.64 & 0.871 \\
\hline 7 & Earnings per share & $13.3 \%$ & $6.1 \%$ & $17.3 \%$ & $63.3 \%$ & 3.31 & 1.068 \\
\hline
\end{tabular}

\section{Conclusion and implication:}

Bangladesh stock market represents itself as an imperfect one because of wide fluctuation in volume of stock trading and market index. It has been claimed that this imperfection in the stock market is an artifact of price manipulation, insider trading, presence of syndicate, lack 
of adequate control, lack of suitable policies and intervention by regulatory bodies. It was found in this study that a great percentage of the total respondents were more or less influenced by the other investors and brokerage house personnel. Moreover, they didn't consider financial performance of the relevant companies in stock trading. They mostly considered the past prices of the stock and changes in market index but didn't try to identify the causes of these changes analyzing financial performance of the listed organizations. Furthermore, $32 \%$ of the respondents were under HSC or below education level and eventually most of them should not have sophisticated stock valuation knowledge but only $5.30 \%$ of total respondents always used expert opinion in stock trading. "Net asset per share" which is known as book value per share and to some extent gives an idea about the value of a particular stock but inversely $46 \%$ of total respondents never used this variable in decision making. Macroeconomic environment of a country affect stock price movement in a country but unfortunately majority of our investors disinclined in considering this factor while making investment decision. Moreover, a certain portion of the retail investors always try to collect information in advance from insider personals of the relevant company. So, all the responsibilities of price instability cannot be shifted to third parties; retail investors themselves are responsible to some extent because of their irrational behavior in stock trading. Although some of the factors are beyond the control of the retail investors, to some extent they can reduce this price instability by enhancing their awareness and share valuation skills and behaving rationally in the stock trading.

\section{References}

AL-Shubiri, F. (2010). Analysis The Determinants of Stock Market Price Movements- An Empirical Study of Jordanian Commercial Bank. International Journal of Business and Management, 5(10), 137-147.

Andriantomo, \& Yudianti, F. (2013). The Value Relevance of Accounting Information at Indonesia Stock Exchange. International Conference on Business, Economics, and Accounting. Bangkok - Thailand: IBEA.

Baskin, J. (1989). Dividend Policy and Volatility of Common Stock. Journal of Portfolio Management, 15(3), 19-25. http://dx.doi.org/10.3905/jpm.1989.409203

Bayezid, A., \& Tanbir, A. (2010). "Effect of Dividend on Stock Pricein Emerging Stock Market: A study on the Listed Private Commercial Banks in DSE. International journal of Economics and Finance, 4, 52-64.

Bhatt, P., \& Sumangula,J. K. (2012). Impact of Earning Per Share on Market Value of An Equity Share: An Emprical Study on Indian Capital Market. Journal of Finance, Accounting and Management, 3(2), 1-14.

Chowdhury, A., \& Abdullah, M.N. (2011). Overheated Stock Market: Remedial Measures for Soft Landing. Journal of Institute of Cost \& Management Accounts of Bangladesh, 5, 28-39.

Dimitrios, T. (2003). Macroeconomic Factors and Stock Prices in the Emerging Cypriot Equity Market. Managerial Finance, 4, 87-92. 
Ghosh, P. K., Bose, T. K., \& Shahriar, M. (2012). Constraints Obstructing Smooth Operation of Capital Market in Bangladesh and Probable Solutions to Those Constraints-An Empirical Study Based on Investors Perception. Indian Journal of Finance, 6(10), 39-52.

Halonen, E., Pavlovic, J., \& Persson, R. (2013). Value relevance of accounting information and its impact on stock prices: Evidence from Sweden. Stockholm University, Department of Economics. Econometrics.

Haque, S., \& Faruquee,M. (2013). Impact of Fundamental Factors on Stock Price: A Case Based Approach on Pharmaceutical Companies Listed with Dhaka Stock Exchange. International Journal of Business and Management Invention, 2(9), 34-41.

Ibrahim, M. H. (1999). Macroeconomic Variables and Stock Prices in Malaysia: An Empirical Analysis. Asian Economic Journal, 13(2), 219-231. http://dx.doi.org/10.1111/1467-8381.00082

Kumar, \& Hundal. (1986). Stock Market Integration Examining Linkages between India and Selected Asian Markets. Foreign Trade Review, 45, 3-18.

Kurihara, U. (2006). The Relationship between Exchange Rate and Stock Prices during the Quantitative Easing Policy in Japan. International Journal of Business, 11(4), 375-386.

Malhotra, V. (1987). Determinants o Equity Prices in India. Himachal University, Shimla.

Ohlson, J. A. (1995). Earnings, Book values and Dividends in Equity Valuation. Contemporary Accounting Research, 11(2), 661-687. http://dx.doi.org/10.1111/j.1911-3846.1995.tb00461.x

Piotroski, J. D., \& Roulstone, D.T. (2004). The Influence of Analysts, Institutional Investors, and Insiders on the Incorporation of Market, Industry and Firm-Specific Information into $\begin{array}{llll}\text { Stock Prices. } & \text { Accounting } & \text { 1119-1151. }\end{array}$ http://dx.doi.org/10.2308/accr.2004.79.4.1119

Sharma, S. (2011). Determinants of Equity Share Prices in India. Journal of Arts Science and Commerce, 2(4), 51-60.

Svensson, E. \& Larsson, A. (2009). Value Relevance of Accounting Information- A Swedish Perspective. Gothenburg: School of Economics and Commercial Law at Gothenburg University.

Tuli, Nishi, \& Mittal, R.K. (2001). Determinants of Price-Earnings Ratios. Finance India, 15(4), 1235-1250.

Yartey, C. A. (2008). The Determinants of Stock Market Development in Emerging Economies: Is South Africa Different? Working paper, International Monetary Fund. http://dx.doi.org/10.5089/9781451868944.001 
Appendixes

Appendix 1. Test of sampling adequacy

KMO and Bartlett's Test

\begin{tabular}{|lcr|r|}
\hline $\begin{array}{l}\text { Kaiser-Meyer-Olkin } \\
\text { Adequacy. }\end{array}$ & Measure of Sampling & .825 \\
Bartlett's $\quad$ Test & of Approx. Chi-Square & $2.083 \mathrm{E} 3$ \\
Sphericity & Df & 325 \\
& Sig. & .000 \\
\hline
\end{tabular}


Appendix 2. Rotated component matrix of factor analysis

Rotated Component Matrix ${ }^{\text {a }}$

\begin{tabular}{|c|c|c|c|c|c|c|c|}
\hline & \multicolumn{7}{|c|}{ Component } \\
\hline & 1 & 2 & 3 & 4 & 5 & 6 & 7 \\
\hline Earnings per share & .320 & .112 & .250 & .049 & -.048 & -.058 & .710 \\
\hline Return on equity ratio & .834 & .213 & .123 & .038 & -.046 & .014 & .104 \\
\hline Return on asset ratio & .838 & .144 & .155 & .153 & -.081 & .038 & .093 \\
\hline Net asset per share & .679 & .076 & .115 & .239 & -.096 & .128 & .347 \\
\hline Debt-equity ratio & .725 & .097 & .092 & .195 & -.169 & .151 & .275 \\
\hline Dividend payout ratio & .601 & .096 & .312 & .200 & -.056 & .131 & .383 \\
\hline Free cash flow & .759 & .143 & .202 & -.020 & .079 & .245 & -.133 \\
\hline Cash reinvestment ratio & .758 & .258 & .219 & .011 & .115 & .039 & -.221 \\
\hline $\begin{array}{l}\text { Reputation of the } \\
\text { company }\end{array}$ & .132 & .018 & .757 & -.050 & .034 & .015 & -.002 \\
\hline Dividend declaration & .224 & .090 & .720 & .086 & -.067 & .080 & .231 \\
\hline Past Price of the stock & .077 & .022 & .844 & -.070 & -.082 & .071 & .217 \\
\hline $\begin{array}{l}\text { Release of new products } \\
\text { or services }\end{array}$ & .341 & .057 & .582 & .093 & .066 & .172 & -.194 \\
\hline $\begin{array}{l}\text { Fluctuations in market } \\
\text { index }\end{array}$ & .137 & .105 & .649 & .227 & -.258 & -.078 & -.032 \\
\hline SEC intervention & .340 & .383 & .236 & .381 & .006 & .075 & -.378 \\
\hline Rate of inflation & .176 & .852 & .015 & -.005 & .002 & .008 & .067 \\
\hline GDP & .366 & .696 & .028 & -.035 & .003 & .196 & .253 \\
\hline $\begin{array}{l}\text { Currency exchange rate } \\
\text { fluctuation }\end{array}$ & .173 & .739 & -.069 & .040 & -.033 & .292 & -.103 \\
\hline $\begin{array}{l}\text { Changes in govt. } \\
\text { Policies }\end{array}$ & .224 & .588 & .153 & .332 & -.131 & .288 & .109 \\
\hline Margin loan facilities & .133 & .195 & .129 & .009 & .057 & .789 & .014 \\
\hline Rate of interest & .175 & .359 & .057 & .151 & -.042 & .806 & -.065 \\
\hline Global financial aspect & .005 & .673 & .216 & .259 & -.118 & .049 & -.054 \\
\hline Expert opinion & .203 & .189 & -.052 & .716 & .369 & .007 & .054 \\
\hline $\begin{array}{l}\text { Recommendation from } \\
\text { other investors }\end{array}$ & -.062 & -.125 & -.114 & .067 & .821 & -.011 & -.063 \\
\hline $\begin{array}{l}\text { Recommendations from } \\
\text { brokerage house }\end{array}$ & -.050 & -.022 & -.044 & .026 & .888 & .041 & -.007 \\
\hline Political stability & .070 & .316 & .326 & .681 & -.190 & .054 & -.014 \\
\hline Insider information & .306 & -.219 & -.187 & .545 & .113 & .403 & .125 \\
\hline
\end{tabular}




\begin{tabular}{|c|c|c|c|c|c|c|c|}
\hline & \multicolumn{7}{|c|}{ Component } \\
\hline & 1 & 2 & 3 & 4 & 5 & 6 & 7 \\
\hline Earnings per share & .320 & .112 & .250 & .049 & -.048 & -.058 & .710 \\
\hline Return on equity ratio & .834 & .213 & .123 & .038 & -.046 & .014 & .104 \\
\hline Return on asset ratio & .838 & .144 & .155 & .153 & -.081 & .038 & .093 \\
\hline Net asset per share & .679 & .076 & .115 & .239 & -.096 & .128 & .347 \\
\hline Debt-equity ratio & .725 & .097 & .092 & .195 & -.169 & .151 & .275 \\
\hline Dividend payout ratio & .601 & .096 & .312 & .200 & -.056 & .131 & .383 \\
\hline Free cash flow & .759 & .143 & .202 & -.020 & .079 & .245 & -.133 \\
\hline Cash reinvestment ratio & .758 & .258 & .219 & .011 & .115 & .039 & -.221 \\
\hline $\begin{array}{l}\text { Reputation of the } \\
\text { company }\end{array}$ & .132 & .018 & .757 & -.050 & .034 & .015 & -.002 \\
\hline Dividend declaration & .224 & .090 & .720 & .086 & -.067 & .080 & .231 \\
\hline Past Price of the stock & .077 & .022 & .844 & -.070 & -.082 & .071 & .217 \\
\hline $\begin{array}{l}\text { Release of new products } \\
\text { or services }\end{array}$ & .341 & .057 & .582 & .093 & .066 & .172 & -.194 \\
\hline $\begin{array}{l}\text { Fluctuations in market } \\
\text { index }\end{array}$ & .137 & .105 & .649 & .227 & -.258 & -.078 & -.032 \\
\hline SEC intervention & .340 & .383 & .236 & .381 & .006 & .075 & -.378 \\
\hline Rate of inflation & .176 & .852 & .015 & -.005 & .002 & .008 & .067 \\
\hline GDP & .366 & .696 & .028 & -.035 & .003 & .196 & .253 \\
\hline $\begin{array}{l}\text { Currency exchange rate } \\
\text { fluctuation }\end{array}$ & .173 & .739 & -.069 & .040 & -.033 & .292 & -.103 \\
\hline $\begin{array}{l}\text { Changes in govt. } \\
\text { Policies }\end{array}$ & .224 & .588 & .153 & .332 & -.131 & .288 & .109 \\
\hline Margin loan facilities & .133 & .195 & .129 & .009 & .057 & .789 & .014 \\
\hline Rate of interest & .175 & .359 & .057 & .151 & -.042 & .806 & -.065 \\
\hline Global financial aspect & .005 & .673 & .216 & .259 & -.118 & .049 & -.054 \\
\hline Expert opinion & .203 & .189 & -.052 & .716 & .369 & .007 & .054 \\
\hline $\begin{array}{l}\text { Recommendation from } \\
\text { other investors }\end{array}$ & -.062 & -.125 & -.114 & .067 & .821 & -.011 & -.063 \\
\hline $\begin{array}{l}\text { Recommendations from } \\
\text { brokerage house }\end{array}$ & -.050 & -.022 & -.044 & .026 & .888 & .041 & -.007 \\
\hline Political stability & .070 & .316 & .326 & .681 & -.190 & .054 & -.014 \\
\hline Insider information & .306 & -.219 & -.187 & .545 & .113 & .403 & .125 \\
\hline
\end{tabular}

Extraction Method: Principal Component Analysis.

Rotation Method: Varimax with Kaiser Normalization. 


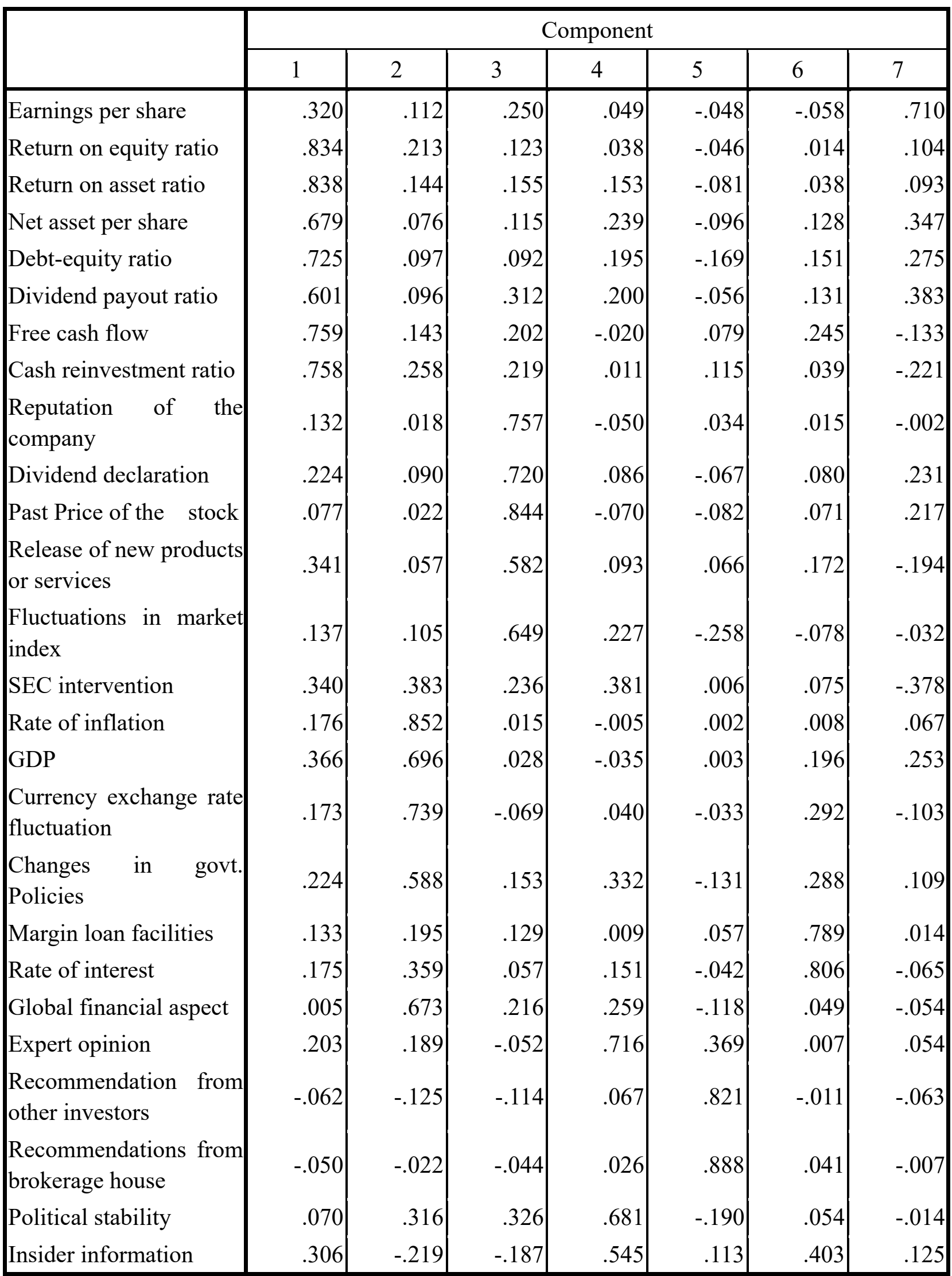

a. Rotation converged in 9 iterations. 